\title{
Simultaneous determination of borax and polyphosphates content in food by liquid chromatography inductively coupled plasma mass spectrometry (LC-ICP-MS)
}

\author{
Dinh Viet Chien ${ }^{*}$, Dang Thi Hien ${ }^{1}$, Nguyen Minh Chau ${ }^{1}$, Le Van Ha ${ }^{1}$, Tran Hoang Giang \\ Lu Thi Minh Hien', Nguyen Van Khoa ${ }^{2}$, Pham Gia Bach ${ }^{2}$, Le Thi Hong Hao ${ }^{1,2}$ \\ ${ }^{1}$ National Institute for Food Control, Hanoi, Vietnam \\ ${ }^{2}$ University of Science, Vietnam National University, Hanoi, Vietnam
}

(Received: 08/04/2021; Accepted: 28/05/2021)

\section{Abstract}

A new method based on LC-ICP-MS technique has been developed and validated for the simultaneous determination of borax and polyphosphates (phosphate, pyrophosphate, tripolyphosphate) in foods. The analytes were extracted from the samples with $18 \mathrm{mM}$ sulfuric acid solution using ultrasonic vibration extraction technique before being filtered and analyzed by LC-ICP-MS system. The method was validated with calibration curves that have the coefficient of determination $\left(\mathrm{R}^{2}\right)$ higher than 0.995 . The method limits of detection (LOD) of borax, phosphate, pyrophosphate (Pyro-P), and tripolyphosphate (Tripoly-P) were in the range of 2.5 to $15.0 \mathrm{mg} / \mathrm{kg}$. The recoveries were in the range of 86.0 to $107.0 \%$ and the relative standard deviations were below 5.23\%. A total of 83 samples of cereal, meat, and seafood-based food were analyzed for research purposes. The results did not indicate a risk of using borax and polyphosphates in most rice products. Meanwhile, meat products including pork paste and roasted pork sold in traditional markets had a borax detection rate of over $60 \%$. This study showed that there was still a risk of using borax in food processing and the use of polyphosphates in food products collected in some districts in Hanoi city.

Keywords: borax, borate, polyphosphate, pyrophosphate, tripolyphosphate, food, LC-ICP-MS.

\section{INTRODUCTION}

From the first application of borax $\left(\mathrm{Na}_{2} \mathrm{~B}_{4} \mathrm{O}_{7}\right)$ confirmed by Arabian goldsmiths and silversmiths in the $8^{\text {th }}$ Century AD [1], borax is widely used both at home and in the industry in many products with roles like laundry detergent booster, cleaner, preservative, fungicide, insecticide, herbicide, disinfectant, and desiccant. With physicochemical properties like odorless, tasteless, easily soluble in water, and the capacity to increase the elasticity and crispiness of foods as well as prevent shrimps from darkening, borax is in the food industry as an additive. However, in 1961, the Joint FAO/WHO Expert Committee on Food Additives (JECFA) declared that this substance is inappropriate in use as a food additive because of leading to adverse reactions to digestion, absorption, nutrient metabolism, and liver, kidneys, brain damage. As a result, it is forbidden to use borax in food production in many countries such as the United States, Thailand, China, and Vietnam. Hence, in Vietnam, polyphosphate substances are regarded as one of the most popular borax-alternative solutions to provide the 
same function in food industry. Polyphosphates (PPs) compounds are used for antioxidants and antibiotics in meat, thank that the products are kept fresher and taste better. In Vietnam, PPs are permitted to use in food production as an additive. The MRLs of these compounds range from 1,320 to $2,200 \mathrm{mg} / \mathrm{kg}$ for fresh meat and heat treat meat products, respectively [2].

The statistic documentaries in recent years prove that borax misuse in meat and meat products. In 2004, monitoring results in pork paste and roasted pork samples in Ho Chi Minh city shown that $64 \%$ over 2,566 collected samples positive with borax [3]. According to another study conducted on samples collected in Dong Da and Hai Ba Trung districts, Hanoi city in 2005, $39.6 \%$ of processed meat samples collected in Dong Da district contained borax. The figure in Hai Ba Trung district was $21.4 \%$ of samples [4]. In the lunar year festival of 2012, approximately $75 \%$ of collected traditional lean pork paste samples in Quang Tri province were positive with borax [5]. Until now, although the borax-detecting frequency in food products is less than in the past, there still have numerous borax-positive cases in Dak Lak, Ha Tinh, Ha Nam provinces [6-8]. Cheaper cost and more popular than polyphosphates additives in the market are the advantages of borax that explains why this substance is used more frequently in food. Therefore, it is necessary to develop a sensitive analytical method to determine simultaneously borax, and polyphosphates content in meat and meat products to control them as the regulation.

Several publications from researchers all around the world discussed borax and polyphosphates quantification. Borax detection in foods is usually assessed through the content of boric acid or sodium tetraborate. For caviar permitted to using borax in production within a regulated threshold, boric acid was determined by UV-Vis method at a wavelength of 555 $\mathrm{nm}$ after derivation with curcumin [9]. Boric acid content in cereals and wheat powder was also quantified by Atomic absorption spectrometry method (AAS) after sample hydrolysis in a mixture of sulfuric acid and nitric acid [10]. Also, chelating-extraction of boron in a solvent containing 2-ethyl-1,3 hexanediol/methyl isobutyl ketone $(15: 85, \mathrm{v} / \mathrm{v})$ was an added step in the sample preparation procedure after microwave digestion, which improved the method to determine boric acid content in AAS system [11].

For determining polyphosphates content, Akinobu Matsugnaga et al. developed an analytical method based on HPLC system utilizing post-column derivatization method [12]. Polyphosphates were extracted from the matrix by using $4 \%$ trichloroacetic acid. A Protein Pak G-DEAE (Waters Co.) anion-exchange column was optimized in the mobile phase condition of $0.01 \mathrm{M}$ nitric acid. And UV-Vis wavelength of measurement was $500 \mathrm{~nm}$. The solutions used in post-column reaction were $0.5 \mathrm{mM} \mathrm{FeCl}_{3}$ and $2.5 \mathrm{mM}$ sulfosalicylic acid. The recovery of the method varied from 90.0 to $100.2 \%$ in cheese and kamaboko matrices. Ion exchange chromatography method was applied in the research of Marco Iammarino et al. on meat, milk, and fish with a gradient elution program using sodium hydroxide [13]. The coefficient of determination $\left(\mathrm{R}^{2}\right)$ was higher than 0.996 , the coefficient of variation was less than $4.5 \%$, and the recovery was in the range of 87.2 to $101.1 \%$. In addition, a method of capillary electrophoresis using a contactless conductivity detector (CE-C4D) was developed to analyze pyrophosphate and triphosphate in some food samples by N. T. Lien et al. [14]. Besides, manufacturers such as Thermo Scientific, and Shodex also conducted their research to determine polyphosphates [15-16].

Obviously, the identification of borax and polyphosphates is not difficult. However, no studies have identified these substances simultaneously. In Vietnam, the abuse of borax in food 
is quite common, while alternative additives such as polyphosphates are also beginning to be of interest. Having a method to simultaneously identify analytes is important in shortening the time to evaluate and monitor product quality for food safety inspection. This study was conducted to develop, validate, and apply the method for simultaneous determination of borax and polyphosphates content in food using LC-ICP-MS, providing a technical solution for the control of these compounds in Vietnam.

\section{MATERIALS AND METHODS}

\subsection{Standards, reagents, and materials}

All chemicals and reagents used in the study were of analytical grade. Sodium pyrophosphate (with purity $>95 \%$ ) and sodium tripolyphosphate (with purity $>85 \%$ ) both were purchased from Sigma-Aldrich (Germany). Boron and phosphate standard solutions and other chemicals including nitric acid, sulfuric acid, hydrochloric acid, disodium ethylenediaminetetraacetate were obtained from Merck Vietnam (Hanoi, Vietnam). All dilutions were done using 18.2 $\mathrm{M} \Omega . c \mathrm{~m}$ de-ionized water (Millipore, Integral, Merck, Germany). Argon and helium gases were supplied from Messer (Vietnam, with purity $>99.999 \%$ ). In addition, equipment standardization solutions were also used for system operation (Perkin Elmer, USA).

\subsection{Solutions preparation}

Pyrophosphate and tripolyphosphate stock solutions were prepared at 1,000 ppm by dissolving sodium pyrophosphate and sodium tripolyphosphate in deionized water. The working standard solutions of boron $(1-10 \mu \mathrm{g} / \mathrm{mL})$, phosphate, and pyrophosphate $(2.5-40 \mu \mathrm{g} / \mathrm{mL})$ were prepared collectively, while tripolyphosphate $(2.5-40 \mu \mathrm{g} / \mathrm{mL})$ was made separately. The working standard solutions were diluted with $18 \mathrm{mM}$ nitric acid using plastic volumetric flasks and were done freshly before daily analysis. The mobile phase and sample extract were prepared and diluted by using deionized water.

\subsection{Instrumentation}

A Flexar Quanternary LC pumps system was coupled to a Perkin Elmer NexION 350X ICP-MS to determine borax and polyphosphates. The analytes were separated in NI-424 Shodex anion exchange column ( $4.6 \mathrm{~mm}$ internal diameter, $100 \mathrm{~mm}$ ) with the mobile phase of $18 \mathrm{mM}$ nitric acid (A) and $18 \mathrm{mM}$ sulfuric acid (B); both contained $0.05 \mathrm{Mm}$ EDTA, at the flow rate of $0.85 \mathrm{~mL} /$ minute. The gradient program was initially set up at $80 \% \mathrm{~A}$ in three minutes. After that, the eluent composition gradually decreases to $20 \% \mathrm{~A}$ in five minutes before returning $80 \%$ in four minutes for the next injection.

\subsection{Sample preparation}

An accurately weighed amount of sample in the range of 0.5 to 1.0 gram was transferred into a $50 \mathrm{~mL}$ centrifuge tube. Then, approximately $40 \mathrm{~mL}$ of $18 \mathrm{mM}$ sulfuric acid was added before being vigorously shaken by a vortex mixer. The tube was placed in an ultrasonic bath at $40^{\circ} \mathrm{C}$ in 30 minutes. After being cool down to room temperature, the tube was centrifuged at $6,000 \mathrm{rpm}$ in five minutes, then the supernatant layer was transferred into a $50 \mathrm{~mL}$ plastic volumetric flask and diluted to the volume. The extracted was passed through a $0.45 \mu \mathrm{m}$ PTFE membrane and analyzed by LC-ICP-MS. 


\subsection{Method validation}

The method was validated with parameters including specificity, linearity, the method limit of detection (LOD), the method limit of quantitation (LOQ), precision, and trueness. The method specificity was assessed by comparing the chromatograms of the blank sample and the spiked blank sample at the level of analytes as in the standard solution. The analyte levels in spiked blank samples giving the signal-to-noise $(\mathrm{S} / \mathrm{N})$ ratios of three and ten were LOD and LOQ, respectively. Repeatability and recovery were evaluated by analyzing three different samples spiked with analytes before extraction. Each spiked sample was analyzed in triplicate.

\section{RESULTS AND DISCUSSION}

\subsection{Optimization of ICP-MS condition}

Boron has two different isotopes including ${ }^{10} \mathrm{~B}(10.0129 \mathrm{~g} / \mathrm{mol})$ accounting for $19.9 \%$ and ${ }^{11} \mathrm{~B}(11.0093 \mathrm{~g} / \mathrm{mol})$ accounting for $80.1 \%$ in nature. Boron isotopes are relatively less affected by interferences, so the more common ${ }^{11} \mathrm{~B}$ isotope was chosen for quantification. Meanwhile, phosphor has only one isotope of ${ }^{31} \mathrm{P}(30.9938 \mathrm{~g} / \mathrm{mol})$ that can be influenced by isobaric polyatomic interferences such as $\mathrm{NOH}, \mathrm{SiH}, \mathrm{NO}$. Therefore, the simultaneous analysis of these elements should be done in collision mode to eliminate interferences. Other parameters were optimized by instrument guidelines. Details of the operating conditions were given in Table 1 .

Table 1. ICP-MS instrument operating conditions

\begin{tabular}{cccc}
\hline ICP-MS parameter & Setting & ICP-MS parameter & Setting \\
\hline RF power $(W)$ & 1,300 & Mass & ${ }^{31} \mathrm{P},{ }^{11} \mathrm{~B}$ \\
Nebulizer gas flow $(\mathrm{L} / \mathrm{min})$ & 0.82 & Mode & Kinetic Energy \\
Plasma gas flow $(\mathrm{L} / \mathrm{min})$ & 19.0 & Helium gas (mL/min) & 3.0 \\
Deflector voltage $(\mathrm{V})$ & 1,000 & Dwell time (ms) & 1,000 \\
\hline
\end{tabular}

\subsection{Optimization of LC condition}

Boron retention times in all cases were less than three minutes and the signal was recorded in a separate mass number with high selectivity. Therefore, this study focused on selecting mobile phase components to solve the problem of separation and quantification of polyphosphates. The initial study was referenced by guidelines for anion NI-424 column (Shodex) using a mobile phase consisting of $9 \mathrm{mM}$ sulfuric acid and $0.05 \mathrm{mM}$ EDTA [14]. However, the elution and analysis times of the substances were relatively long (approximately 20 minutes) increasing the consumption cost factors and reducing the sensitivity of the method (Figure 1A). As the sulfuric acid concentration was increased, the analytes were eluted earlier rising the sensitivity of the method (Figure 1B). Nevertheless, the phenomenon of the peak of phosphate $\left(\mathrm{PO}_{4}^{3-}\right)$ being split had not been resolved. On the other hand, a mobile phase with the complete use of sulfuric acid was not conducive to atomization and ionization of analytes. In addition, sulfuric acid easily causes precipitation of insoluble salts with metal ions making the higher pressure than usual through the separating column. 

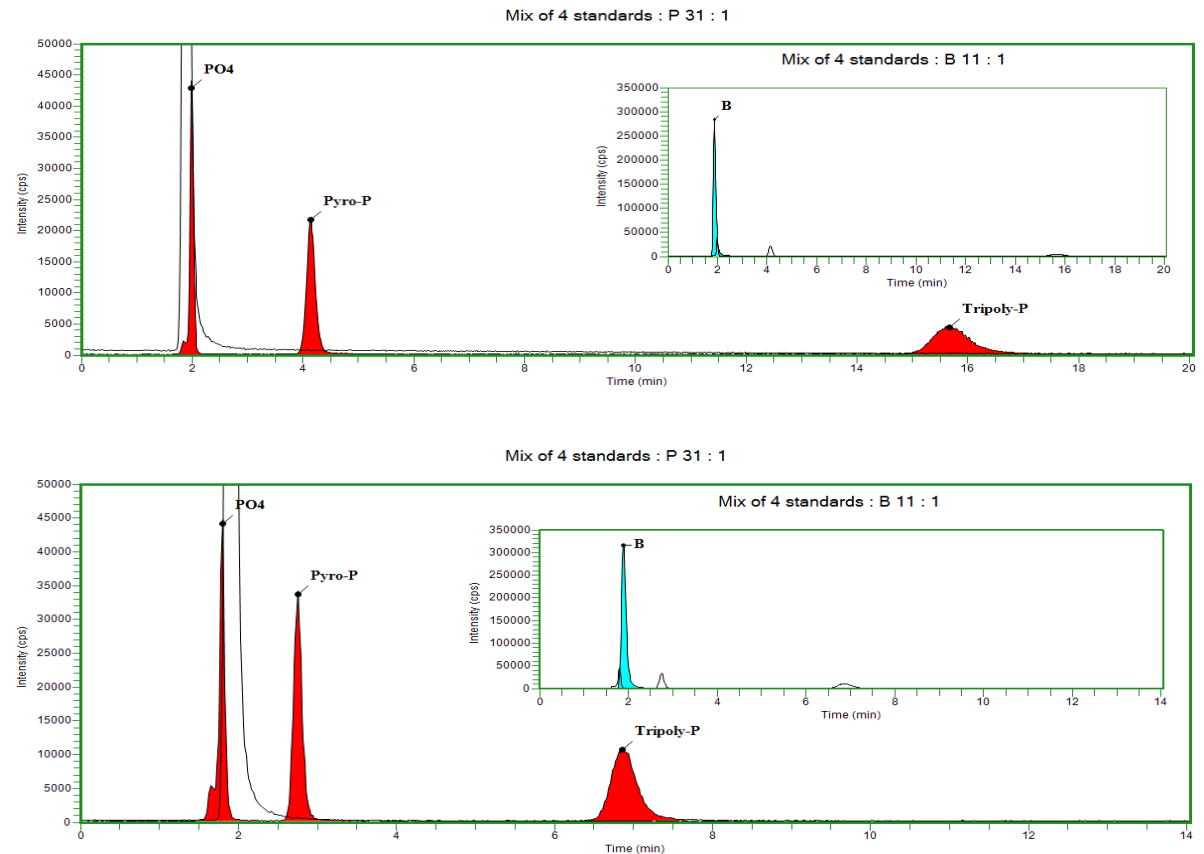

Figure 1. Chromatograms of (A) $\mathrm{PO}_{4}^{3-}$, Pyro- $P 10$ ppm and Tripoly-P $25 \mathrm{ppm}$ in the mobile phase of $0.05 \mathrm{mM}$ EDTA, $9 \mathrm{mM} \mathrm{H}_{2} \mathrm{SO}_{4}$ and (B) $\mathrm{PO}_{4}^{3-}$, Pyro-P 10 ppm and Tripoly-P 25 ppm in the mobile phase of $0.05 \mathrm{mM}$ EDTA, $18 \mathrm{mM} \mathrm{H}_{2} \mathrm{SO}_{4}$

In this study, the other acid components more favorable to the ICP-MS processes such as nitric acid, hydrochloric acid with equivalent concentrations were investigated. The use of these acids showed less elution efficiency than sulfuric acid. However, in the case of using nitric acid as the mobile phase, the peak shape of phosphate was obtained being not split like sulfuric acid was used, and the separating column pressure tended to be lower and more stable. Therefore, the investigation of the mobile phase gradient elution of $18 \mathrm{mM}$ sulfuric acid (channel A) and 18 $\mathrm{mM}$ nitric acid (channel B) containing $0.05 \mathrm{mM}$ EDTA simultaneous was conducted to obtain the highest analytical efficiency (Figure 2).

Mix 4 stds : $P 31: 1$

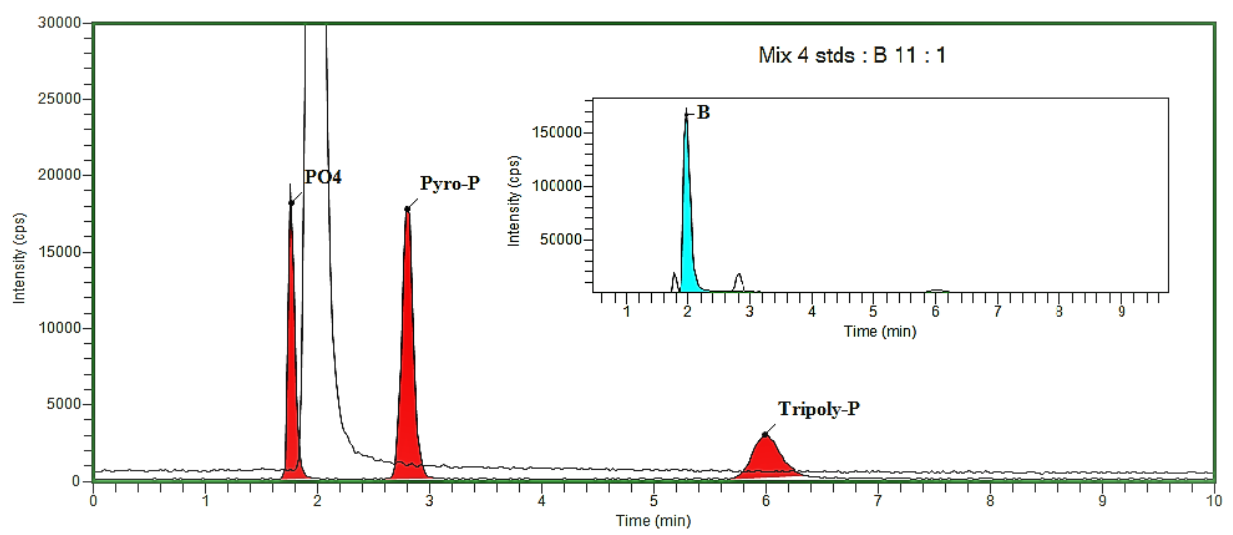

Figure 2. Chromatogram analyzing substances according to the optimal gradient program

All substances were eluted within seven minutes and the total analysis time was about 12 minutes that were suitable for the quantification of these compounds. 


\subsection{Investigation of the effect of sample extraction solvents}

Studies have shown that, in addition to treating samples using concentrated acids, boron and its salts could also be extracted in deionized water or diluted acid solvents. Meanwhile, deionized water is normally used to be a solvent extracting phosphate and polyphosphate compounds. In this study, deionized water and acid components of the mobile phase including $18 \mathrm{mM}$ nitric acid and $18 \mathrm{mM}$ sulfuric acid were selected to investigate the effect of extraction solvent. The results were given in Figure 3.

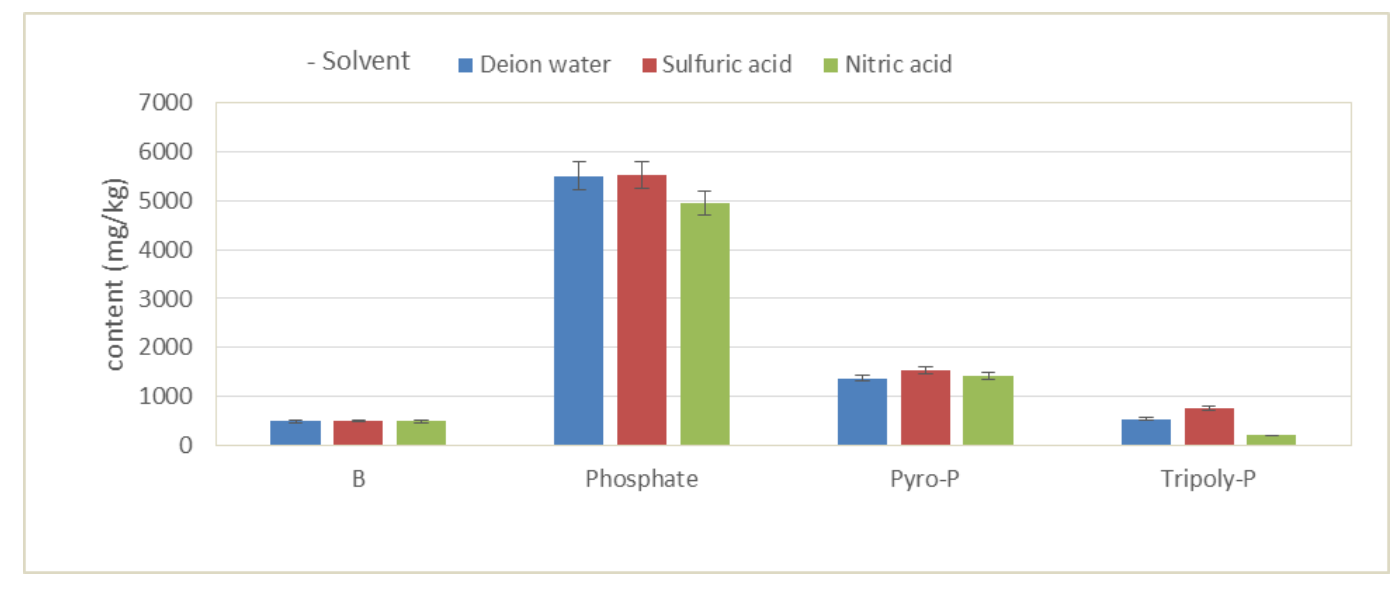

Figure 3. Investigation of the effect of extraction solvents on polyphosphates analysis

The bar chart showed the different solvents giving extraction efficiency equivalent to Boron while using $18 \mathrm{mM}$ sulfuric acid gave better extraction efficiency with phosphate and polyphosphate compounds. Thus, $18 \mathrm{mM}$ sulfuric acid was chosen as the extraction solvent to carry out further investigations for sample treatment process.

\subsection{Investigation of the effects of extraction time and temperature}

After selecting the extraction solvent, other conditions were also investigated to obtain the optimum parameters for the extraction process such as extraction time and temperature. The extraction time was studied in the range of 15 to 40 minutes with each step of five minutes and the extraction temperature in the range of 30 to $80^{\circ} \mathrm{C}$ with each transition being $10^{\circ} \mathrm{C}$. The results were indicated in Figure 4.
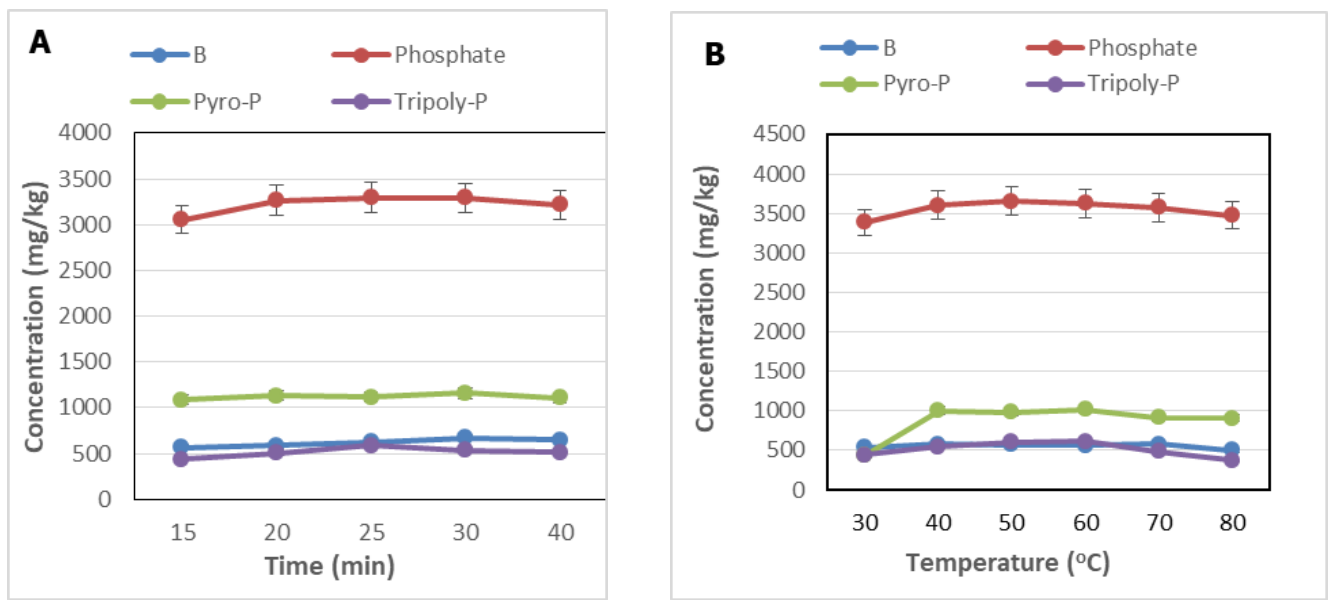

Figure 4. The effects of sample extraction time (A) and temperature (B) 
Figure 4 showed the concentration of analytes increases with extending extraction time, while polyphosphates tend to decrease with increasing extraction temperature. The optimal extraction time and temperature were selected at 30 minutes and $40^{\circ} \mathrm{C}$, respectively. At that values, the highest and stable concentration of borax and polyphosphates extracted from the sample matrix were obtained.

\subsection{Method validation}

The method specificity was assessed by comparing the chromatograms of the blank sample and the spiked blank sample at the same level of analytes in the standard solution. The chromatograms of blank samples (Figure 5) did not show analytes peak compare to the case of spiked blank samples, and standard solutions. This result demonstrated that the method has good specificity.

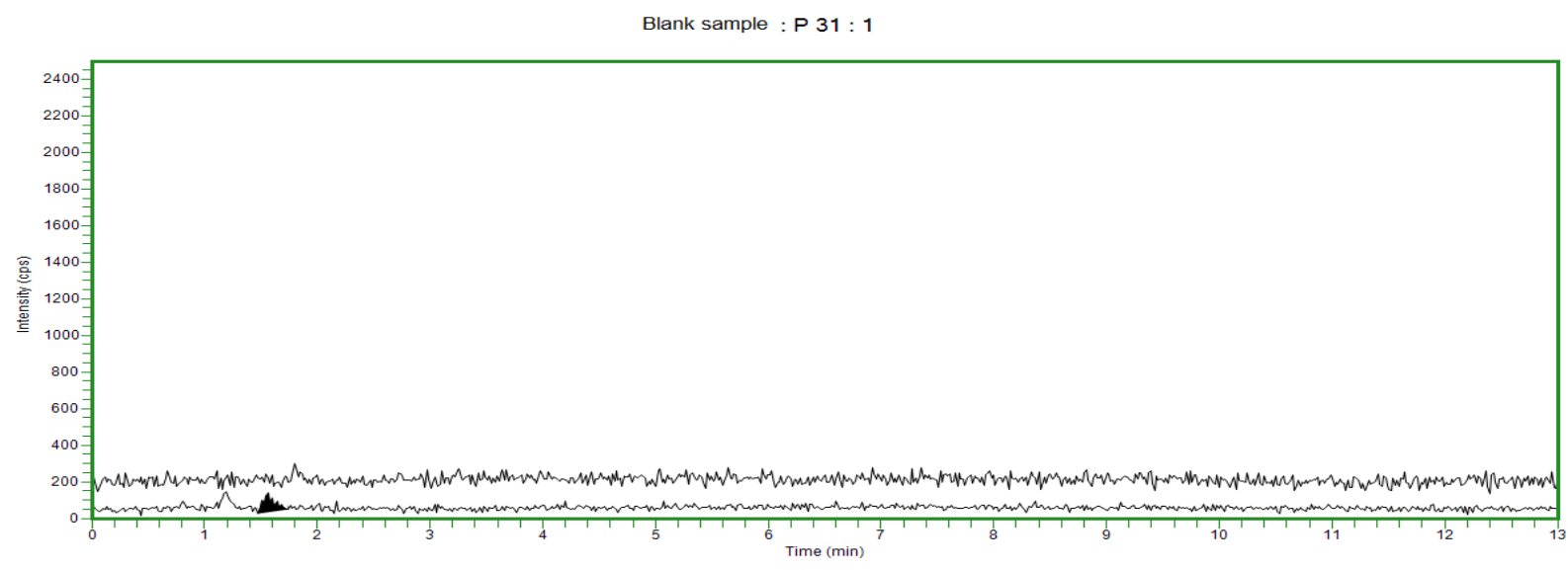

Figure 5. The chromatogram of a blank sample

The LOD and LOQ of borate were at 2.5 and $7.5 \mathrm{mg} / \mathrm{kg}$, while pyro-P and tripoly-P were at 15 and $45 \mathrm{mg} / \mathrm{kg}$, respectively (Figure 6). The LOQ of borate is fit for determining borax in food products at a very low level compare to AAS and UV-vis methods [8-10]. The LOQ of polyphosphates was not as low as that of the ion chromatography studies [11-12], but it is suitable for the purpose of analyzing and controlling the phosphate additive group in food as prescribed.

Blank spiked LOQ : B 11 : 1

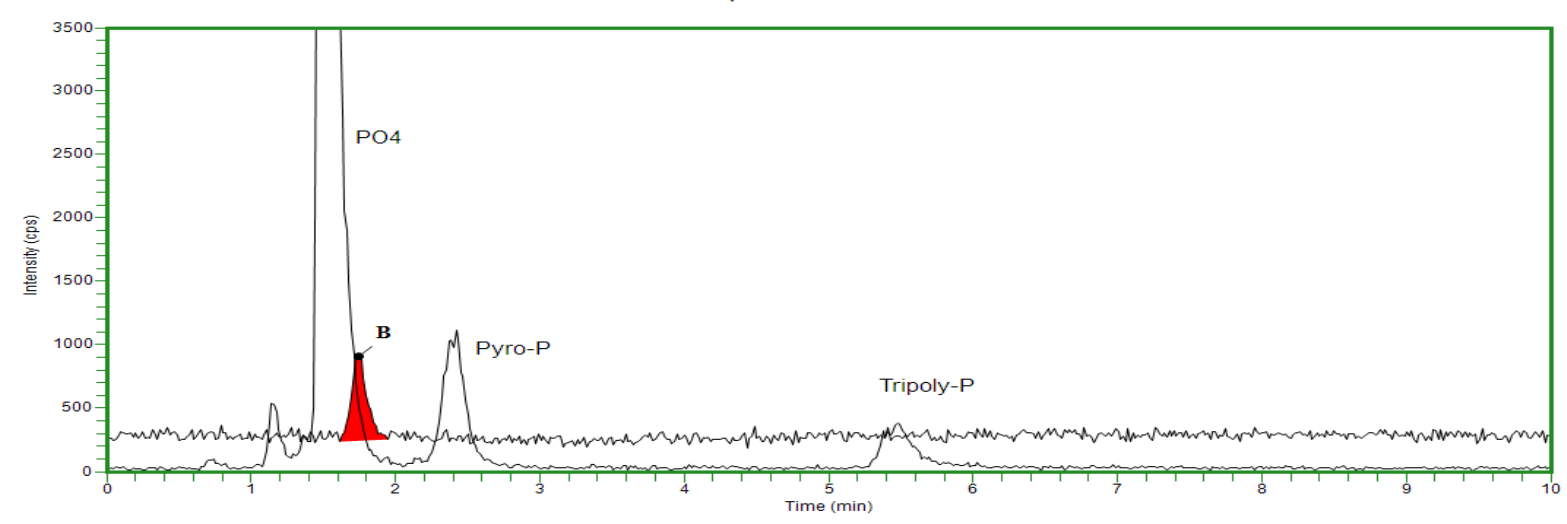

Figure 6. The chromatogram of analytes at the LOQ level 
The calibration curves showed good linearity with the coefficient of determination $\left(\mathrm{R}^{2}\right)$ higher than 0.995 . The relative standard deviations for all substances were below 5.23\%, while the recovery from 86 to 107\%. Details of validated parameters were given in Table 2.

Table 2. The results of method validation

\begin{tabular}{cccccccc}
\hline Substance & $\begin{array}{c}\text { Calibration curve } \\
\text { equation }\end{array}$ & $\begin{array}{c}\text { Range } \\
(\boldsymbol{\mu g} / \mathbf{m L})\end{array}$ & $\boldsymbol{R}^{2}$ & $\begin{array}{c}\text { LOD } \\
(\mathbf{m g} / \mathbf{k g})\end{array}$ & $\begin{array}{c}\text { LOQ } \\
(\mathbf{m g} / \mathbf{k g})\end{array}$ & RSDr (\%) & $\boldsymbol{R}(\%)$ \\
\hline Boron & $\mathrm{y}=43792 \mathrm{x}-1607.7$ & $1.0-10$ & 0.9999 & $2.5^{*}$ & $7.5^{*}$ & $3.95-4.30$ & $98.8-107$ \\
Phosphate & $\mathrm{y}=3163.1 \mathrm{x}+2.6667$ & $2.5-40$ & 1.0000 & 5.0 & 15 & $0.51-5.23$ & $101-104$ \\
Pyro-P & $\mathrm{y}=2077.2 \mathrm{x}-62.167$ & $2.5-40$ & 0.9997 & 15 & 45 & $0.68-1.96$ & $92.6-103$ \\
Tripoly-P & $\mathrm{y}=3238.6 \mathrm{x}-756.93$ & $2.5-50$ & 0.9999 & 15 & 45 & $1.74-4.71$ & $86.0-105$ \\
\hline
\end{tabular}

${ }^{(*)}$ The LOD and LOQ of Borate

The method was validated with the parameters meeting the AOAC performance requirements, showing that the method was completely fit for determining borax and polyphosphate species in food.

\subsection{Analysis of food samples}

The validated method was used for analyzing 83 samples with nine kinds of different foods collected on markets in Hanoi city. The results were summarized in Table 3.

Table 3. Analysis results of borax and polyphosphates in food samples

\begin{tabular}{lcccc}
\hline \multicolumn{1}{c}{ Samples/number } & $\begin{array}{c}\text { Borate } \\
(\mathbf{m g} / \mathbf{k g})\end{array}$ & $\begin{array}{c}\text { Phosphate } \\
(\mathbf{m g} / \mathbf{k g})\end{array}$ & $\begin{array}{c}\text { Pyro-P } \\
(\mathbf{m g} / \mathbf{k g})\end{array}$ & $\begin{array}{c}\text { Tripoly-P } \\
(\mathbf{m g} / \mathbf{k g})\end{array}$ \\
\hline Fresh rice noodles $(\mathrm{n}=12)$ & - & $124-147$ & $38.0-118$ & - \\
Pho $(\mathrm{n}=11)$ & - & - & - & - \\
Pyramidal rice dumpling $(\mathrm{n}=09)$ & $54-444$ & $123-1,181$ & $2221^{*}$ & - \\
Lean pork paste $(\mathrm{n}=16)$ & $82-4,214$ & $1,431-4,436$ & $23.0-820$ & - \\
Roasted pork $(\mathrm{n}=16)$ & $1,383-6,342$ & $2,042-5,255$ & $106-647$ & - \\
Jambon $(\mathrm{n}=7)$ & - & $2,895-6,762$ & $64.0-1,983$ & - \\
Fermented pork roll $(\mathrm{n}=2)$ & - & $1,649-3,935$ & - & - \\
Canned meat $(\mathrm{n}=5)$ & - & $1,861-5,973$ & $61.0-1,884$ & - \\
Fresh meat $(\mathrm{n}=3)$ & - & $3,000-4,500$ & $200-270$ & - \\
Canned fish $(\mathrm{n}=5)$ & - & $1,415-7,708$ & $228-313$ & - \\
\hline
\end{tabular}

* Only detected in one sample 
Based on the results in Table 3, it can observe that the whole rice-based food products such as fresh noodles and Pho were less risk of using borax than the meat products group. However, products derived from rice powder and meat also showed a risk of containing borax of 3/9 pyramidal rice dumpling samples detecting borax content of $54.0-444 \mathrm{mg} / \mathrm{kg}$. In which, one analyzed sample in total had pyro-P, and tripoly-P content of 2,221 mg/kg, and 1,799 mg/ $\mathrm{kg}$, respectively.

The group of meat-processed products collected from traditional markets showed a high rate of borax detection. In detail, 10/16 (62.5\%) samples of the lean pork paste and 11/16 (68.8\%) roasted cinnamon pork detected borax (Table 4). These figures were two to three times higher than another survey report in Dong Da, Hai Ba Trung districts, Hanoi since 2005 [4], and were equivalent to the borax-positive ratio in Ho Chi Minh City in 2004 [3]. It could observe that although the authorities have disseminated propaganda about the harms of borax, as well as severe sanctions, the use of borax in small and individual businesses was still going on at an alarming rate. Meanwhile, in contrast, $100 \%$ of processed, packaged, and canned products sold by branded manufacturers did not have borax.

Table 4. The rate of borax detection in several food products

\section{Samples}

Fresh rice noodles

Pho

Pyramidal rice dumpling

Lean pork paste

Roasted pork

Jambon

Fermented pork roll

Canned meat

Fresh meat

\section{Borax detection rate (\%)}

Not detected

Not detected

33.3

68.8

Not detected

Not detected

Not detected

Not detected

The tripolyphosphate was not recognized in the analyzed meat products. But it could be negligence if based on these results to confirm whether having the use of tripolyphosphate in processing meat products or not. Since tripolyphosphate might hydrolyze into forms of pyrophosphate or monophosphate during heat treatment as well as interaction with enzymes existing during production and preservation [17]. For example, a lot of products are reported using tripolyphosphate (E451i) which were not recorded any responses after the analysis procedure. The results showed in Figure 7. 


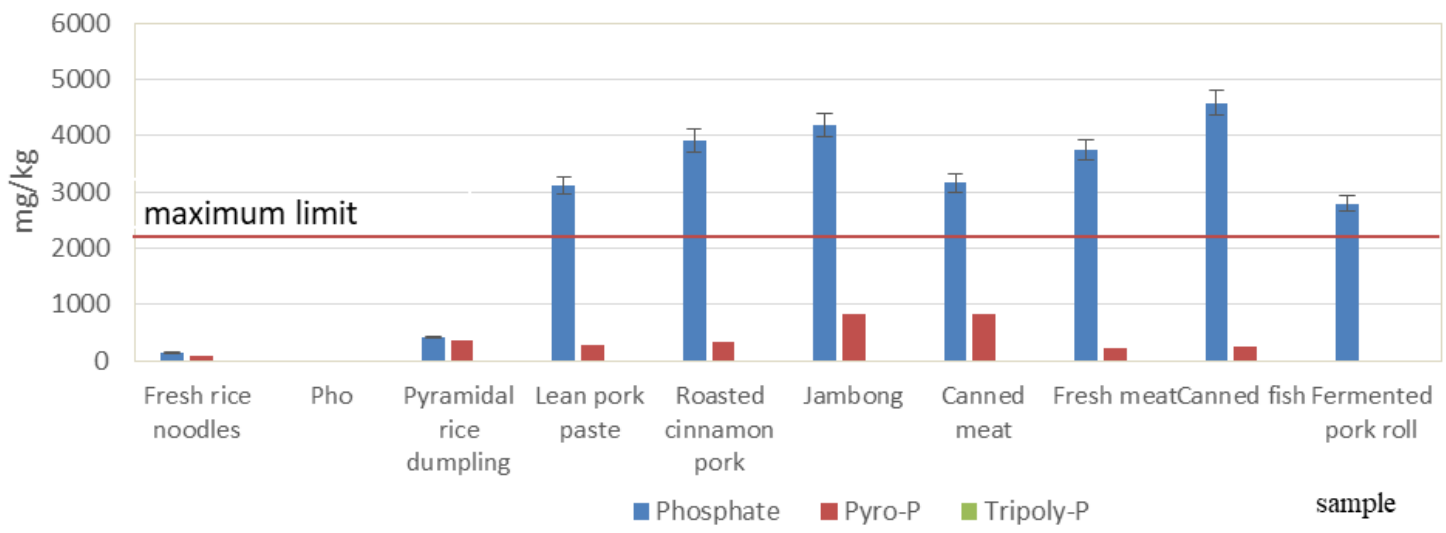

Figure 7. The average content of polyphosphates

Figure 7 showed the average concentrations of polyphosphates in the products studied. The results indicated that in addition to the risk of having borax in meat products for storage and processing purpose, the high total phosphate content of the products was also a concern. According to the provisions of Circular 24/2019/TT-BYT, the total phosphate content as an additive in meat, seafood, products derived from them is maximum at 2,200 $\mathrm{mg} / \mathrm{kg}$. The phosphate content in meat and seafood is in the range of $1,415-7,708 \mathrm{mg} / \mathrm{kg}$, which not including pyrophosphate. However, phosphate and pyrophosphate are also available in the organism in nature. The analysis results of three fresh lean pork samples showed a high level of phosphate and pyrophosphate in the range of 3,000 - 4,500 mg/kg and $200-270 \mathrm{mg} / \mathrm{kg}$, respectively (Table 3 ). Therefore, it could not be concluded whether the phosphate in the food product has a natural origin or is added as a preservative additive.

From the analysis of real samples, it could be preliminarily assessed that the current status of using borax in the processing of steamed and fried pork ham products in traditional markets is still an alarming issue and affects consumers' health. The study also revealed initial results on the relatively high content of phosphate and polyphosphates in food. The research topic still has some limitations as the less studied seafood samples, as well as larger-structure polyphosphates have not been studied yet.

\section{CONCLUSIONS}

The method for simultaneous determination of the borax and polyphosphates contents in food by LC-ICP-MS was optimized through analytical conditions on the equipment and investigated factors in sample preparation. Validation parameters meet the requirements of AOAC standards. The research group applied the method in analyzing the content of borax and polyphosphates in a total of 83 samples divided into nine different foods collected in several districts in Hanoi city. The results showed that most rice-derived products did not have any risk of having borax and polyphosphates. Meanwhile, meat products including pork paste and roasted pork sold in traditional markets have a prevalence rate of over $60 \%$ borax detection. The meat product group also showed high phosphate content, and pyrophosphate detection rate was above $90 \%$. Also, further research is necessary to accurately assess whether the high level of phosphate in products is naturally sourced or added as a food additive. 


\section{ACKNOWLEDGEMENT}

We would like to thank the National Institute for Food Control for the funding of this study.

\section{REFERENCES}

[1]. "Borax $\left(\mathrm{Na}_{2} \mathrm{~B}_{4} \mathrm{O}_{7} \cdot 10 \mathrm{H}_{2} \mathrm{O}\right)$ - Sodium Borate - Occurrence, Discovery and Applications," Amoz.com. August 16, 2004.

[2]. The Circular 24/2019/TT-BYT, Regulations on management and use of food additives.

[3]. Thanh Tung, Formol is still rampant in pho - Borax is still spreading in spring rolls, https:// thanhnien.vn/suc-khoe/formol-van-tran-lan-trong-pho-han-the-van-tran-lan-tronggio-cha-325759.htmL, 2006.

[4]. D. T. Hoa, N. T. K. Dung, and T. X. Bach, “The situation of using borax and illegal food coloring in some processed foods at some markets in Dong Da and Hai Ba Trung districts - Hanoi 2005," Journal Practical Medicine, no. 10, 2007.

[5]. Quang Tri Sub-Department of Food Safety and Hygiene, "The issue of using borax in food," http://antoanthucpham.quangtri.gov.vn/Tin-tuc-su-kien/Van-de-su-dung-han-thetrong-thuc-pham-16.html, December 19, 2012.

[6]. T. H. Hoai, "Evaluation of food contamination in Dak Lak province from 2014 2018," Vietnamese Journal of Food Control. vol. 2, no. 3, pp. 44-50, 2019.

[7]. N. Duong, Ha Nam, "Fined VND 40 million, temporarily suspending production facilities using solder," http://daidoanket.vn/an-toan-thuc-pham/ha-nam-phat-40-trieu-dong-tamdinh-chi-co-so-san-xuat-gio-su-dung-han-the-tintuc456124, January 4, 2020.

[8]. B. Nhung, "Powerless to control welding used to process and preserve food, https://baohatinh. vn/y-te/bat-luc-trong-kiem-soat-han-the-dung-che-bien-bao-quan-thuc-pham/148008. htm, January 17, 2018.

[9]. AOAC Official Method 969.26, Spectrophotometric Method - Boric Acid in Caviar.

[10]. AOAC Official Method 972.19, Atomic Absorption Spectrophotometric Method - Boric Acid in Food.

[11]. AOAC Official Method 975.26, Emission Spectroscopic Method - Boric Acid in Food.

[12]. Akinobu Matsunaga, Atsushi Yamamoto, Eiichi Mizukami, and Tooru Ooizumi, "Determination of Polyphosphates in Foods by High Performance Liquid Chromatography," Published by Japanese Society for Food Science and Technology, vol. 37, no. 1, pp. 20-25, 1990.

[13]. Marco Iammarino, Aurelia Di Taranto, "Determination of polyphosphates in products of animal origin: application of a validated ion chromatography method for commercial samples analyses," European Food Research and Technology, vol. 235, pp. 409-417, 2012.

[14]. N. T. Lien, N. T. A. Huong, C. V. Hoang, P. Q. Trung, and L. T. H. Hao, "Study on the process of simultaneous analysis of pyrophosphate and triphosphate in some food samples by capillary electrophoresis using non-contact conductivity detector (CE-C $\left.{ }^{4} \mathrm{D}\right)$," Journal of Analytical Chemistry, Physics and Biology, vol. 23, no. 1, pp. 121-127, 2018.

[15]. Thermo Scientific, Determination of polyphosphates using ion chromatography, Application update 172, 2016.

[16]. Shodex, Application search, analysis of pyrophosphate and tripolyphosphate [online], https://www.shodex.com/en/dc/07/06/15.html [Accessed date: 15/12/2020].

[17]. ISO 5553:1980. Meat and meat products - Detection of polyphosphates 


\title{
Xác định đổng thời hàm lượng hàn the và các polyphosphate trong thực phẩm bằng phương pháp sắc ký lỏng ghép nối khối phổ plasma cao tần cảm ứng (LC-ICP-MS)
}

\author{
Đinh Viết Chiến ${ }^{1^{*}}$, Đặng Thị Hiên ${ }^{1}$, Nguyễn Minh Châu ${ }^{1}$, Lê Văn Hà ${ }^{1}$, Trần Hoàng Giang \\ Lũ Thị Minh Hiền ${ }^{1}$, Nguyễn Văn Khoa ${ }^{1}$, Phạm Gia Bách ${ }^{2}$, Lê Thị Hồng Hảo ${ }^{1,2}$ \\ ${ }^{1}$ Viện Kiêm nghiệm an toàn vệ sinh thực phẩm Quốc gia, Hà Nội, Việt Nam \\ ${ }^{2}$ Trường Đại học khoa học Tự nhiên, Đại học Quốc gia Hà Nội, Việt Nam
}

Tóm tắt

Phương pháp LC-ICP-MS đã được phát triển và thẩm định nhằm xác định đông thời hàn the và các dạng polyphosphate (phosphate, pyrophosphate, tripolyphosphate) trong thực phẩm. Các chất phân tích được chiết ra khỏi nền mẫu bằng dung dịch acid sulfuric $18 \mathrm{mM}$ sử dụng kỹ thuật chiết siêu âm, trước khi được lọc và phân tích trên hệ thống LC-ICP-MS. Phương pháp đã được thẩm định với các đường chuẩn cho hệ số tương quan tuyến tính $\mathrm{R}^{2}>0,995$. Giới hạn phát hiện của phương pháp với hàn the, phosphate, pyrophosphate và tripolyphosphate trong khoảng 2,5 - 15,0 mg/kg. Hiệu suất thu hồi trong khoảng 86,0 - 107,0\% và độ lệch chuẩn tương đối lặp lại nhỏ hơn 5,23\% cho thấy phương pháp có độ đúng và độ chụm tốt. Phương pháp được áp dụng để phân tích đồng thời hàm lượng của hàn the và polyphosphate trong 83 mẫu thực phẩm các loại có nguôn gốc ngũ cốc, thịt và thủy sản. Kết quả cho thấy, không có nguy cơ sử dụng hàn the và polyphosphate trong hâuu hết các sản phẩm chế biến từ ngũ cốc. Trong khi đó, các sản phẩm thịt như giò và chả quế bán ở các chợ truyền thống có tỉ lệ phát hiện hàn the trên $60 \%$. Kết quả nghiên cứu này cho thấy vẫn còn nguy cơ sử dụng hàn the trong chế biến thực phẩm.

Tư khóa: hàn the, polyphosphate, pyrophosphate, tripolyphosphate, thực phâm, LC-ICP-MS. 